\title{
Kinetics and Mechanism of the Pyridinolysis of Aryl Phenyl Isothiocyanophosphate in Acetonitrile
}

\author{
Keshab Kumar Adhikary, Hai Whang Lee, and Ikchoon Lec ${ }^{*}$ \\ Department of Chemistr, Inha University, Inchon $702-751$. Korea \\ Received April t, 2003
}

\begin{abstract}
The kinetics and mechanism of the pyridinolysis $\left(\mathrm{XC}_{5} \mathrm{H}_{4} \mathrm{~N}\right)$ of $\mathrm{Y}$-aryl phenyl isothiocyanophosphates ( $\mathbf{1}$ : $\left.\left(\mathrm{YC}_{6} \mathrm{H}_{4} \mathrm{O}\right)\left(\mathrm{C}_{6} \mathrm{H}_{5} \mathrm{O}\right) \mathrm{P}^{\prime}(=\mathrm{O}) \mathrm{NCS}\right)$ are investigated in acetonitrile at $55.0^{\circ} \mathrm{C}$. The Hammett plots for substituent (Y) variations in the substrate ( $\log _{2} k_{2} v \sigma_{Y}$ ) exhibit a convex upward biphasic type with breaks at $\mathrm{Y}=\mathrm{H}$. For electron-donating $Y$ groups the Hammett coefficients, $\rho_{Y}$, are positive and cross-interaction constant $\rho_{X Y}$ is negative, while those for electron-withdrawing $\mathrm{Y}$ groups $\rho_{Y}$ values are negative with a positive $\rho_{X Y}$. These results are interpreted to indicate mechanistic change at the breakpoint $\left(\sigma_{Y}=0\right)$ from a concerted to a stepwise mechanism with rate-limiting expulsion of the NCS group from a trigonal bipyramidal pentacoordinated (IBP-5C) intermediate. Biphasic plots of $\log k_{2}$ is $\sigma_{X}$ or $\mathrm{pK}_{3}(\mathrm{X})$ with steeper slopes for the more basic nucleophiles are obtained suggesting an equatorial nucleophilic attack in contrast to an apical attack for the less basic nucleophiles with smaller magnitude of $\rho_{x}$ or $\beta_{x}$.
\end{abstract}

Key Words : Pyridinolysis, Aryl phenyl isothiocyanophosphates, Cross-interaction constant

\section{Introduction}

Phosphoryl transfers from phosplate monoesters and diesters are an important class of reaction that is involved in many aspects of chemistry and biochemistry ranging from organic synthesis through enzyme catalyzed reactions such as DNA replication and repair.' $\Lambda$ considerable amount of work has been carried out to clarify the problem whether the phosphoryl transice reactions proceed concentedly with a single transition state (TS) or stepwise with a pentacoordinated phosphorane intermediate. ${ }^{1.2}$

In our previous works ${ }^{3}$ the aminolyses of diphenyl chlorophosphate and 4-chlorophenyl Y-substituted phenyl chlorophosphates have been studied in acetonitrile. The anilinolysis of diphenyl chlorophosphate ${ }^{\text {3a }}$ proceeds through a concerted pathway but unexpectedly with a late TS. The anilinolysis of 4-chlorophenyl Y-phenyl chlorophosphates ${ }^{30}$ proceeds through a concerted pathway with a relatively larger magnitude of $\rho_{X}$ and $\beta_{X}$ values indicating a larger degree of bond formation than diphenyl chlorophosphate in the TS. The pyridinolysis of diphenyl chlorophosphate ${ }^{\text {it }}$ proceeds concertedly with an early TS in which the extent of both bond formation and leaving group departure is small.

$A$ dramatic result was found recently in the investigation of the reactions of Z-aryl bis(4-methoxyphenyl) phosphates, $\left(4-\mathrm{MeOC}_{6} \mathrm{I}_{4} \mathrm{O}\right)_{2} \mathrm{P}(-\mathrm{O}) \mathrm{OC}_{6} \mathrm{I}_{4} \mathrm{Z}$, with $\mathrm{X}$-pyridines. $\left(\mathrm{XC}_{5} \mathrm{I}_{4} \mathrm{~N}\right)$, in acetonitrile. ${ }^{+}$In the case of the more basic phenolate leaving groups, the mechanism changes from a concerted process for the less basic pyridines 10 a stepwise process with rate-limiting formation of a trigonal bipyramidal pentacoordinated (TBP-5C) intermediate for the more basic pyridines. In the case of the less basic phenolate leaving groups, the reaction proceds through a direct backside atlack TBP-5C.

In this work we extend our sludies of the mechanism of phosphoryl transfer reactions to the pyridinolysis of Y-aryl phenyl isothiocyanophosphate (1) in acetonitrile at $55^{\circ} \mathrm{C}$, cq. 1.

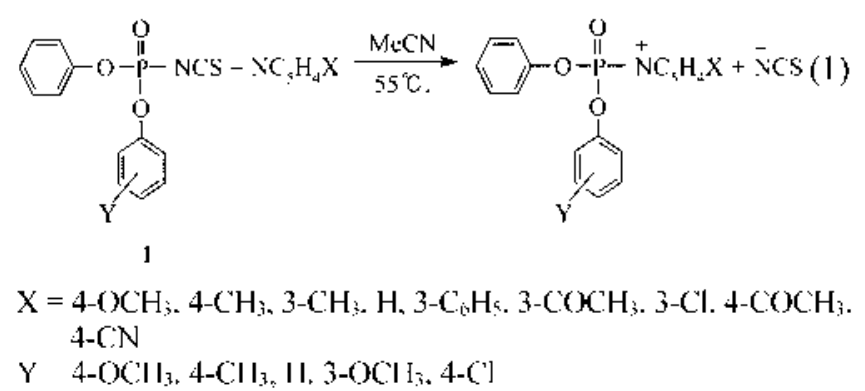

Isothiocyanophosphates are used in various organic synthesis. I iang and coworkers" reported new derivatizing reagents for C-terminal peptide sequencing at low nanomole levels and they showed that diphenyl isothiocyanophosphate is one of the superior reagents due to its double function of activation and derivatization. Diphenyl isothiocyanophosphate is also used as an automated carboxy-terminal secuence analysis of peptides and proteins." Kristian and coworkers" have developed a new simple method for preparation of $\alpha$ isothiocyanatoethers from $\mathrm{P}(=\mathrm{O})(\mathrm{NCS})_{5}$ or $(\mathrm{PhO})_{2} \mathrm{P}(=\mathrm{O}) \mathrm{NCS}$ with an equimolar mixture of aldehydes and alcohols.

Our interest in the present work is centered in the mechanistic change and / or TS structure variation associated with the substituent changes in the substrate $(\mathrm{Y})$ and nucleophile $(\mathrm{X})$ in the phosphoryl transfer involving isothiocyanate leaving group, NCS , by determining the Hammett $\left(\rho_{X}, \rho_{Y}\right)$ and Brönsted coefficients $\left(\beta_{Y}\right)$, and cross-interaction constants $^{8}\left(\rho_{\times Y}\right)$ in eqs. 2 where $\mathrm{X}$ and $\mathrm{Y}$ denote the substituents in the nucleophile and the substrate, respectively.

$$
\begin{gathered}
\log \left(k_{X Y} / k_{H H}\right)-\rho_{Y} \sigma_{X}-\rho_{Y} \sigma_{Y}-\rho_{X Y} \sigma_{X} \sigma_{Y} \\
\rho_{X Y}=\partial \rho_{Y} / \partial \sigma_{X}=\partial \rho_{X} / \partial \sigma_{Y}
\end{gathered}
$$


It should be noted that the previous studies ${ }^{+}$were concemed with the mechanistic changes due to the substituent variations in the nucleophile $(\mathrm{X})$ and the leaving group $(\mathrm{Z})$. in contrast to the substituent changes in the nucleophile $(X)$ and the substrate (Y) in the present work.

\section{Results and Discussion}

The pseudo-first-order rate constants observed ( $k_{0}$ bsil $)$ were found to follow eq. 3 for all the reactions under pseudo-firstorder condition with a large excess of pyridine

$$
h_{\text {olsd }}=h_{0}+k_{2}[\mathrm{Py}]
$$

nucleophile. The $k_{0}$ values were negligible $\left(k_{0} \approx 0\right)$ in acetonitrile. The second-order rate constants. $k_{2}\left(\mathrm{M}^{-1} \mathrm{~s}^{-1}\right)$. collected in Table 1 were determined for at least five pyridine concentrations. [Py]. The overall reaction is described by eq. 1 without any complications arising from side reactions.

The rate constants $k_{2}$ are subjected to Hammett correlation (Figures 1 and 2 ) and the Hammett coefficients $\rho_{\mathrm{X}}$ and $\rho_{\mathrm{Y}}$ are

Table 1. Second-Order Rate Constants, $k_{2} \times 10^{4}\left(\mathrm{M}^{-1} \mathrm{~s}^{-1}\right)$, for the Reactions of Y-Aryl Phenyl Isothiocyanophosphates with XPyridines in Acetonitrile at $55.0^{\circ} \mathrm{C}$

\begin{tabular}{lclllll}
\hline \multicolumn{1}{c}{$\mathrm{Y}^{2}$} & $4-\mathrm{OCH}_{3}$ & $4-\mathrm{CH}_{3}$ & $\mathrm{H}$ & $3-\mathrm{OCH}$ & $4-\mathrm{Cl}$ \\
\hline $4-\mathrm{OCH}_{3}$ & 382 & 611 & 1750 & 988 & 230 \\
$4-\mathrm{CH}_{3}$ & 85.9 & 116 & 255 & 151 & 50.9 \\
$3-\mathrm{CH}_{3}$ & 62.2 & 81.0 & 170 & 95.6 & 35.5 \\
$\mathrm{H}$ & 9.65 & 13.6 & 30.2 & 17.4 & 6.72 \\
$3-\mathrm{C}_{6} \mathrm{H}_{3}$ & 4.21 & 6.54 & 13.9 & 7.80 & 3.45 \\
$3-\mathrm{COCH}_{3}$ & 0.469 & 0.701 & 2.23 & 1.19 & 0.555 \\
$3-\mathrm{Cl}_{4}$ & 0.402 & 0.653 & 1.86 & 0.746 & 0.417 \\
$4-\mathrm{COCH}_{3}$ & 0.353 & 0.606 & 1.37 & 0.682 & 0.408 \\
$4-\mathrm{CN}$ & 0.322 & 0.543 & 1.14 & 0.600 & 0.326 \\
\hline
\end{tabular}

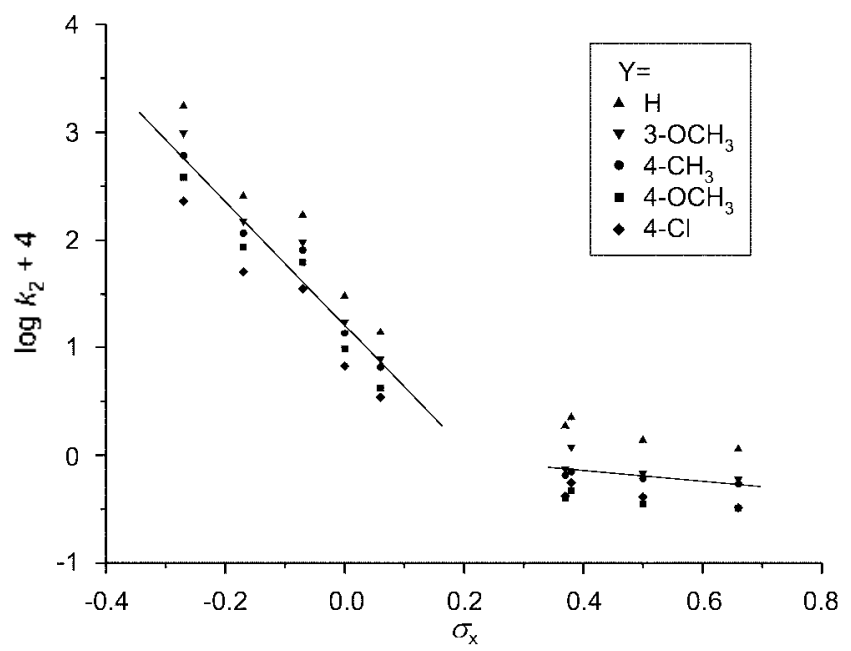

Figure 1. The Hammett plots for the reactions of Y-aryl phenvl isothiocyanophosphates with $\mathrm{X}$-pyridines in acetonitrile at $5500^{\circ} \mathrm{C}$. determined as summarized in Table 2. In addition. the Brösted coefficients $\left(\beta_{X}\right)$ are derived from the slopes of the

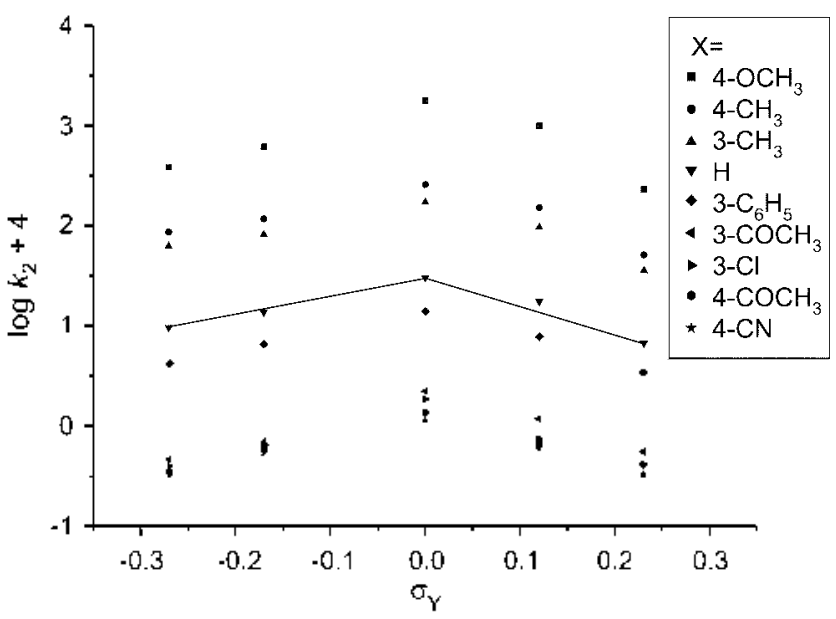

Figure 2. The Hammett plots for the reactions of $\mathrm{Y}$-aryl phenyl isothiocyanophosphates with $\mathrm{X}$-pyridines in acetonitrile at $55.0^{\circ} \mathrm{C}$.

Table 2. Selectivity Parameters ${ }^{a}$ for the Reactions of Y-Aryl Phenyl Isothiocyanophosphates with X-Pyridines in Acetonitrile at $55.0^{\circ} \mathrm{C}$

\begin{tabular}{|c|c|c|c|c|}
\hline \multirow{2}{*}{$\mathrm{Y}$} & \multicolumn{2}{|c|}{$\mathrm{X}=4-\mathrm{OCH}_{3}-3-\mathrm{C}_{6} \mathrm{H}_{5}$} & \multicolumn{2}{|c|}{$\mathrm{X}=3-\mathrm{COCH}_{3}-4-\mathrm{CN}$} \\
\hline & $\rho_{\mathrm{x}}$ & $\beta_{\mathrm{x}}$ & $\rho_{\mathrm{x}}$ & $\beta_{\mathrm{X}}$ \\
\hline $4-\mathrm{OCH}_{3}$ & $\begin{array}{c}-5.75 \pm 0.21 \\
(0.972)^{4}\end{array}$ & $\begin{array}{c}1.21 \pm 0.21 \\
(0.993)\end{array}$ & $\begin{array}{c}-0.46 \pm 0.04 \\
(0.882)\end{array}$ & $\begin{array}{c}0.12 \pm 0.01 \\
(0.990)\end{array}$ \\
\hline $4-\mathrm{CH}_{3}$ & $\begin{array}{c}-5.79 \pm 0.19 \\
(0.977)\end{array}$ & $\begin{array}{c}1.22 \pm 0.10 \\
(0.994)\end{array}$ & $\begin{array}{c}-0.33 \pm 0.02 \\
(0.954)\end{array}$ & $\begin{array}{c}0.08 \pm 0.01 \\
(0.996)\end{array}$ \\
\hline $\mathrm{H}$ & $\begin{array}{c}-6.12 \pm 0.19 \\
(0.980)\end{array}$ & $\begin{array}{c}1.28 \pm 0.11 \\
(0.993)\end{array}$ & $\begin{array}{c}-0.90 \pm 0.06 \\
(0.933)\end{array}$ & $\begin{array}{l}0.22 \pm 0.02 \\
(0.994)\end{array}$ \\
\hline $3-\mathrm{OCH}_{3}$ & $\begin{array}{c}-6.14 \pm 0.18 \\
(0.982)\end{array}$ & $\begin{array}{c}1.28 \pm 0.10 \\
(0.994)\end{array}$ & $\begin{array}{c}-0.69 \pm 0.11 \\
(0.721)\end{array}$ & $\begin{array}{c}0.20 \pm 0.06 \\
(0.917)\end{array}$ \\
\hline \multirow[t]{3}{*}{$4-\mathrm{Cl}$} & $\begin{array}{c}-5.38 \pm 0.18 \\
(0.978)\end{array}$ & $\begin{array}{c}1.13 \pm 0.09 \\
(0.994)\end{array}$ & $\begin{array}{c}-0.58 \pm 0.07 \\
(0.828)\end{array}$ & $\begin{array}{c}0.15 \pm 0.03 \\
(0.954)\end{array}$ \\
\hline & \multicolumn{2}{|c|}{$4-\mathrm{OCH}_{3}-\mathrm{H}$} & \multicolumn{2}{|c|}{$\mathrm{H}-4-\mathrm{Cl}$} \\
\hline & \multicolumn{2}{|c|}{$\rho_{Y}$} & \multicolumn{2}{|c|}{$\rho_{Y}$} \\
\hline $4-\mathrm{OCH}_{3}$ & \multicolumn{2}{|c|}{$2.47 \pm 0.03(0.998)^{b}$} & \multicolumn{2}{|c|}{$3.81 \pm 0.17(0.963)$} \\
\hline $4-\mathrm{CH}_{3}$ & \multicolumn{2}{|c|}{$1.78 \pm 0.04(0.995)$} & \multicolumn{2}{|c|}{$3.03 \pm 0.11(0.975)$} \\
\hline $3-\mathrm{CH}_{3}$ & \multicolumn{2}{|c|}{$1.65 \pm 0.04(0.993)$} & \multicolumn{2}{|c|}{$2.94 \pm 0.09(0.984)$} \\
\hline $\mathrm{H}$ & \multicolumn{2}{|c|}{$1.86 \pm 0.03(0.997)$} & \multicolumn{2}{|c|}{$2.82 \pm 0.08(0.984)$} \\
\hline $3-\mathrm{C}_{6} \mathrm{H}_{5}$ & \multicolumn{2}{|c|}{$1.92 \pm 0.01(0.999)$} & \multicolumn{2}{|c|}{$2.62 \pm 0.05(0.992)$} \\
\hline & \multicolumn{2}{|c|}{$\rho_{\mathrm{XY}}=-1.42 \pm 0.18(0.957)$} & \multicolumn{2}{|c|}{$\rho_{\mathrm{XY}}=+3.16 \pm 0.18(0.960$} \\
\hline $3-\mathrm{COCH}_{3}$ & \multicolumn{2}{|c|}{$2.56 \pm 0.06(0.992)$} & \multicolumn{2}{|c|}{$2.62 \pm 0.03(0.997)$} \\
\hline $3-\mathrm{Cl}$ & \multicolumn{2}{|c|}{$2.49 \pm 0.03(0.998)$} & \multicolumn{2}{|c|}{$2.83 \pm 0.05(0.995)$} \\
\hline $4-\mathrm{COCH}_{3}$ & \multicolumn{2}{|c|}{$2.17 \pm 0.01(0.999)$} & \multicolumn{2}{|c|}{$2.29 \pm 0.02(0.998)$} \\
\hline \multirow[t]{2}{*}{$4-C N$} & \multicolumn{2}{|c|}{$2.02 \pm 0.02(0.999)$} & \multicolumn{2}{|c|}{$2.36 \pm 0.01(0.999)$} \\
\hline & \multicolumn{2}{|c|}{$\rho_{\mathrm{XY}}=-1.81 \pm 0.04(0.983)$} & \multicolumn{2}{|c|}{$\rho_{\mathrm{XY}}=+1.40 \pm 0.07(0.951$} \\
\hline
\end{tabular}

"The $\sigma$ values were taken from Hansch. C.: Leo, A.: Taft R. W. Chem. Rev: 1991. 91. 165. The $\beta_{\mathrm{X}}$ talues were detemined using $\mathrm{p} K_{7}$ talues in water. The $\mathrm{NK}_{\mathrm{a}}$ values of pridines in water at $25^{\circ} \mathrm{C}$ were taken from: (i) Dean. J. A. Hondbook of Onganic Chemistry McGraw-Hill: New York. 1987; Chapter 8. (ii) The $\mathrm{p} \mathrm{K}_{\mathrm{a}}$ ralues of $\mathrm{X}=m-\mathrm{C}_{6} \mathrm{H}_{5}$ and $\mathrm{X}=p-\mathrm{CH}_{3} \mathrm{CO}$ were taken from Koh, H. J.: Han, K. L.: Lee. H. W.: Lee, I. J. Org. Chem. 1998, 63, 9834. "Correlation coefficient. 


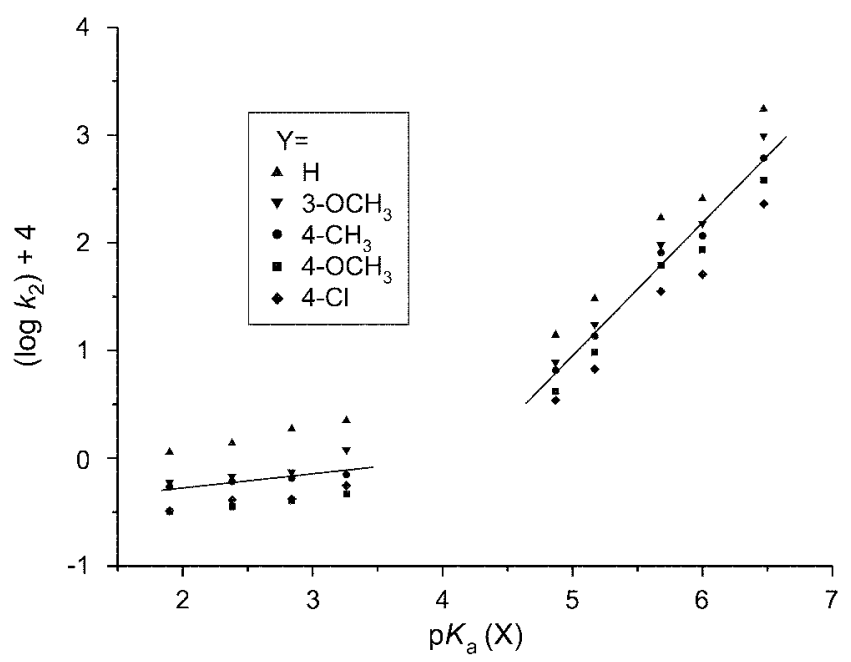

Figure 3. The Bronsted plots for the reactions of Y-aryl phentyl isothiocyanophosphates with $\mathrm{X}$-pyridines in acetonitrile at $55.0^{\circ} \mathrm{C}$.

plots of $\log k_{2}(\mathrm{MeCN})$ against $\mathrm{p} K_{3}\left(\mathrm{X}\right.$ in $\left.\mathrm{H}_{2} \mathrm{O}\right)$ in Figure 3. and are also shown in Table 2 . This procedure of using the $\mathrm{p} K_{\mathrm{a}}\left(\mathrm{H}_{2} \mathrm{O}\right)$ instead of $\mathrm{p} K_{\mathrm{a}}(\mathrm{MeCN})$ values of pyridines has been shown to be justified since there is a practically constant difference between the two sets of $\mathrm{p} K_{\mathrm{a}}{ }^{\prime} \mathrm{s}$ in $\mathrm{H}_{3} \mathrm{O}$ and in $\mathrm{MeCN}$ for various substituted pyridines so that the slopes $\left(\beta_{\mathrm{X}}\right)$ in the two solvents differ insignificantly.

Examination of Figures 1-3 reveals that all the plots are biphasic with break points at $\sigma_{\mathrm{Y}} \cong 0.2$ and $\sigma_{\mathrm{Y}}=0$ in the substituent variation of the nucleoplile and substrate. respectively. For the more basic (stronger) nucleophiles (X= $\left.4-\mathrm{OCH}_{3}-3-\mathrm{C}_{6} \mathrm{H}_{5}\right)$ the magnitude of $\rho_{\mathrm{X}}(=-5.4$ to -6.1$)$ and $\beta_{\mathrm{X}}(=1.1-1.3)$ are larger than those for the less basic (weaker) nucleophiles $\left(\rho_{\mathrm{X}}=-0.3\right.$ to $-0.9: \beta_{\mathrm{X}}=0.1-0.2$ for $\mathrm{X}$ $\left.=3-\mathrm{COCH}_{3}-4-\mathrm{CN}\right)$. Strikingly the sign of slope $\left(\rho_{\mathrm{y}}\right)$ in the plot of $\log k_{2} v \sigma_{Y}$ changes from positive $(=1.6-2.6)$ for electron donor $Y$ to negative $\left(\rho_{\mathrm{Y}}=-2.3\right.$ to -3.8$)$ for electron acceptor $Y$ with a convex upward Hammett plot (Figure 2). This type of Hammett plot normally' suggests a mechanistic change at the breakpoint. ${ }^{16}$ We propose the changeover from a concerted (for $\sigma_{\mathrm{Y}}<0$ ) to a stepwise mechanism with ratelimiting expulsion of the leaving group. ${ }^{-N C S}$. in a trigonal bipyramidal pentacoordinated (TBP-5C) intermediate (for $\sigma_{r}>0$ ). based on the following grounds: The positive sign of $\rho_{Y}$ indicates negative charge development in the TS on the reaction center. P. This is accompanied with a negative sign of the cross-interaction constant $\rho \mathrm{XY}$. which is indicative of a concerted $\left(S_{k} 2\right)$ process $s^{\S}$ or a rate-limiting bond making process in an adduct (or intermediate) formation. ${ }^{11}$ In the latter case. however the magnitude of $\rho \mathrm{xy}$ tends to be rather small. For example addition of amines $\left(\mathrm{XRNH}_{2}\right)$ to olefines $\left(\mathrm{YC}_{6} \mathrm{H}_{4} \mathrm{C}_{b a} \mathrm{H}=\mathrm{C}_{b} \mathrm{Z} . \mathrm{Z}^{\prime}\right)$ in acetonitrile proceeds by a concerted formation of the $\mathrm{C}_{\alpha}-\mathrm{N}$ and $\mathrm{C}_{\beta}-\mathrm{H}$ bonds in a single-step process leading to a neutral product. ${ }^{11}$ For the olefines with various activating (electron-acceptor) groups $\left(Z . Z^{\prime}\right)$, the reactions of benzylamines have led to the $\rho_{\mathrm{XY}}$ values of $-0.31\left(\mathrm{Z} . \mathrm{Z}^{\prime}=\mathrm{CN} . \mathrm{CN}\right){ }^{11 \mathrm{lb}}-0.33\left(1.2-(\mathrm{CO}) \mathrm{C}_{6} \mathrm{H}_{4}\right)^{1{ }^{110}}-0.40$ $\left(\mathrm{NO}_{2} . \mathrm{H}\right)^{1 \mathrm{la}}$ and $-0.52\left(\mathrm{NO}_{3}, \mathrm{C}_{6} \mathrm{H}_{3}\right){ }^{1{ }^{1 \mathrm{~d}}}$ Again. for the rate- limiting formation of a tetrahedral intermediate in the pyridinolysis of phenacyl bromides in acetonitrile the $\rho_{\mathrm{XY}}$ value reported is $c a+0.1{ }^{\text {l' }}$ 'Thus, the magnitude of $\rho_{\mathrm{XY}}$ value is small, either negative or positive. in the rate-limiting bond formation process. In contrast. however. in the concerted. $S_{\mathrm{N}} 2$, process the $\rho_{\mathrm{Y}}$ observed exhibited a rather large negative value. For the $S_{*} 2$ processes involving aminolysis of benzyl. benzenesulfonyl and benzoyl halides. the $\rho_{\mathrm{XY}}$ values reported range from -0.6 to $-1.7^{\text {sa.b }}$ The $\rho_{\mathrm{XY}}$ values obtained in the present work. -1.42 and -1.81 . are therefore in favor of the concerted ( $\mathrm{S} \times 2$ ) mechanism rather than a simple rate-limiting addition mechanism. Additional support for this conclusion is provided by the large $\beta_{\mathrm{X}}\left(\beta_{\text {nuc }}\right)$ values (1.1-1.3) for the more basic pyridine nucleophiles which are considered to be more likely to give stepwise mechanism than less basic nucleophiles. ${ }^{4}{ }^{4} .134$ In a stepwise mechanism. however, the large $\beta_{\mathrm{X}}$ value is an indication of a rate-limiting leaving group expulsion process. ${ }^{13}$ for which $\rho_{\mathrm{XY}}$ is not negative but positive as in the present case.

More importantly this proposal of the concerted mechanism for the reactions of substrates with electron-donating groups $\left(\sigma_{Y}<0\right.$ and $\left.\rho_{\mathrm{Y}}>0\right)$ are in accord with the well known experimental and theoretical results ${ }^{15}$ that the concerted process is favored over the stepwise mechanism by the push provided by the groups that remain behind. In the present case. electron donating $Y$ groups in the substrate provide such a push to expel the leaving group. ${ }^{-}$NCS. and increase the possibility of the reaction proceeding by a concerted mechanism.

In summary, the large negative $\rho_{\mathrm{XY}}$ values coupled with positive $\rho_{\mathrm{Y}}$ and large $\beta_{\mathrm{S}}$ values (for the more basic pyridines) support a concerted process. an associative $S_{\Downarrow 2}$ process with a greater degree of bond-making than bond-cleavage in the TS.

As to the biphasic plots of $\log k_{2}$ is $\sigma_{\mathrm{X}}$ or $\mathrm{p} K_{4}(\mathrm{X})$. we propose the front side (equatorial) attack TS for more basic nucleophiles and backside (apical) attack TS for less basic pyridines. ${ }^{4.14}$ It is well known that a weakly basic group has a greater apicophilicity so that apical approach is favored for such nucleophiles. ${ }^{+1+16 i}$ Since the apical bonds are longer than the equatorial bonds. ${ }^{4.1+}$ the apical nucleophilic attack should lead to a looser $\mathrm{P}-\mathrm{N}$ bond in the TBP-5C structure and hence a smaller magnitude of $\beta_{\mathrm{K}}$ as well as $\rho_{\mathrm{X}}$ is obtained. $^{4}$

Now for the pyridinolysis of substrates with electronwithdrawing groups. we obtained negative $\rho_{Y}$ values. The negative slope suggests either positive charge development. or alternatively a reduction of negative charge at the reaction center. P. in the TS. The electron-withdrawing groups by depleting electrons from the reaction center. P. retard the rate of leaving group departure and a negative $\rho_{Y}$ results. This means that rate-limiting cleavage of the $\mathrm{P}-\mathrm{NCS}$ bond from a TBP-5C intermediate (2) occurs in the TS since the departure of -NCS leaving group leaves behind a partial positive charge in the reaction center. $\mathrm{P}$. in the TS which is stabilized by the oxygen lone pairs $\left(\mathrm{O}^{-}\right)$but is destabilized by the electron attraction from the positive charge on the nitrogen 


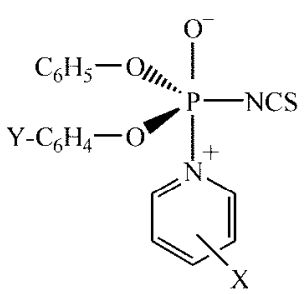

2

$\left(\mathrm{N}^{-}\right)$and electron-withdrawing $\mathrm{Y}$ substituent. On balance. the destabilization of developing positive charge on $\mathrm{P}$ is stronger than the stabilization by the oxygen lone pairs so that the leaving group expulsion is hindered in the TS with the resulting rate retardation. This proposal is supported by the large positive $\rho_{X Y}$ values $(+3.16$ and +1.40$)$ for the reactions of the substrates with electron-withdrawing substituents. ${ }^{15}$ For the rate-limiting breakdown of TBP-5C intermediate. the $\rho_{\mathrm{XY}}$ values were found to be relatively large positive: $\rho_{\mathrm{XY}}=+0.88$. for the anilinolysis of cinnamoyl chlorides $\left(\mathrm{YC}_{6} \mathrm{H}_{4} \mathrm{CH}=\mathrm{CHCOCl}\right)$ in acetonitrile. ${ }^{17}$ and +0.53 for the reactions of $S$-phenyl benzoates $\left(\mathrm{YC}_{6} \mathrm{H}_{4} \mathrm{C}(=\mathrm{O}) \mathrm{SC}_{6} \mathrm{H}_{5}\right)$ with benzylamines in acetonitrile. ${ }^{18}$ Another good example is the aminolysis of phenyl dithiobenzoates $\left(\mathrm{YC}_{6} \mathrm{H}_{4} \mathrm{C}(=\mathrm{S})\right.$ $\mathrm{SC}_{6} \mathrm{H}_{3}$ ) in acetonitrile: the $\rho_{\mathrm{YY}}$ values are +0.7 (partially large. for rate-limiting expulsion of the leaving group from a zwitterionic intermediate. $\mathrm{T}^{3}$ ) and +0.06 (small. for ratelimiting formation of $\mathrm{T}^{ \pm}$) for the aminolysis with anilines and benzylamines. respectively. ${ }^{15}$ Chloride should be a far better leaving group than isothiocyanate. The anilinoly'sis of Y-aryl phenyl chlorophosphate has been shown to proceed by a concerted $(\mathrm{S} \mathrm{V} 2)$ mechanism with $\rho_{\mathrm{YY}}=-1.31{ }^{\text {3a }}$ Change of the leaving group from $\mathrm{Cl}^{-}$to that of a lower leaving ability: -NCS causes a change in mechanism from a concerted to a stepwise process with rate-limiting breakdown of the TBP-5C intermediate.

This is in accord with the well established trend of the mechanistic change depending on the leaving group ability: the lower the leaving ability of the leaving group. the greater is the tendency for a stepwise mechanism with rate-limiting expulsion of the leaving group from the intermedi-

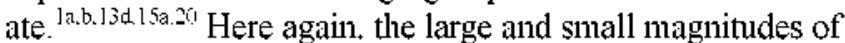
$\rho_{\mathrm{X}}$ and $\beta_{\mathrm{X}}$ values for the more basic and less basic nucleophiles. respectively can be interpreted to indicate formation of the intermediate with equatorial and apical $\mathrm{P}-\mathrm{N}$ (nucleophile) bonds. respectively. . $^{4.14}$

The mechanistic change from a concerted for the substrate with electron-donating $Y$ substituent to a stepwise with ratelimiting breakdown of the TBP-5C intermediate for electronwithdrawing $Y$ can be represented schematically as shown in Figure 4. An electron-donor $Y$ raises the lone pair level on oxygen atoms (no) which results in a greater vicinal no $\rightarrow$ $\sigma_{\text {P.S }}^{*}$ charge transfer interactions ${ }^{21}$ so that bond cleavage of the P-NCS bond is facilitated $=2$ and leads to a concerted process. In contrast. an electron-acceptor $\mathrm{Y}$ depresses the no level resulting in a weaker $n_{O} \rightarrow \sigma_{\text {P.K }}^{*}$ vicinal charge transfer interactions and stabilization of the intermediate ${ }^{166.23}$ This
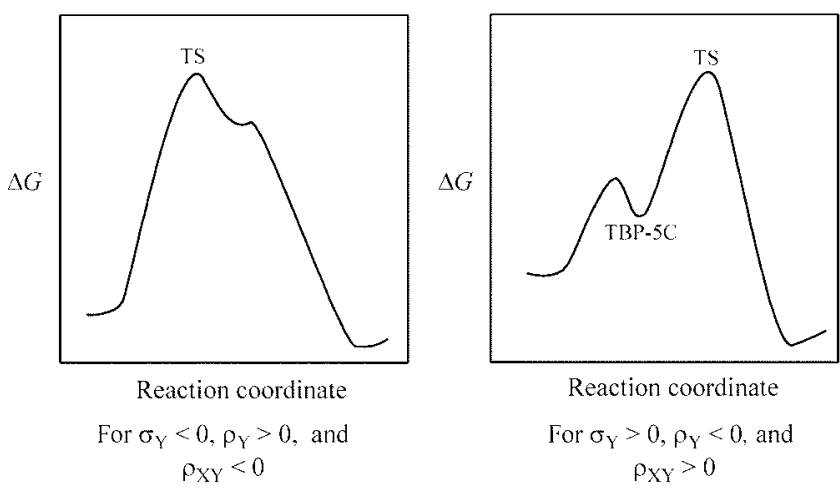

Figure 4. Schematic presentation of the effect of substituent $Y$ in the substrate

Table 3. Activation Parameters ${ }^{\prime \prime}$ for the Reactions of Y-Ary l Phenyl Isothiocyanophosphates with X-Py ridines in Acetonitrile

\begin{tabular}{|c|c|c|c|c|c|}
\hline$X$ & $\mathrm{Y}$ & $t^{\circ} \mathrm{C}$ & $\begin{array}{c}k_{2} \times 10^{-1} / \\
\mathrm{M}^{-1} \mathrm{~s}^{-1}\end{array}$ & $\begin{array}{c}\Delta H^{\dot{*}} / \\
\mathrm{kcal} \mathrm{mol}^{-1}\end{array}$ & $\begin{array}{c}-\Delta S^{\neq} / \\
\mathrm{cal} \mathrm{mol} l^{-1} \mathrm{~K}^{-1}\end{array}$ \\
\hline \multirow[t]{3}{*}{$4-\mathrm{CH}_{3}$} & $4-\mathrm{OCH}_{3}$ & 45 & 64.7 & $60 \pm 0.5^{b}$ & $50 \pm 2^{b}$ \\
\hline & & 55 & 85.9 & & \\
\hline & & 65 & 121 & & \\
\hline \multirow[t]{3}{*}{$3-\mathrm{CH}_{3}$} & $\mathrm{H}$ & 45 & 121 & $6.9 \pm 0.3$ & $46 \pm 1$ \\
\hline & & 55 & 170 & & \\
\hline & & 65 & 246 & & \\
\hline \multirow[t]{3}{*}{$3-\mathrm{Ph}$} & $3-\mathrm{OCH}_{3}$ & 45 & 5.24 & $8.4 \pm 0.1$ & $47 \pm 1$ \\
\hline & & 55 & 7.80 & & \\
\hline & & 65 & 12.2 & & \\
\hline \multirow[t]{3}{*}{$3-\mathrm{COCH}_{3}$} & $4-\mathrm{Cl}$ & 45 & 0.336 & $10.1 \pm 0.1$ & $47 \pm 1$ \\
\hline & & 55 & 0.555 & & \\
\hline & & 65 & 0.920 & & \\
\hline
\end{tabular}

"Calculated by the Eyring equation. "Standard deviation.

will lead to a stepwise mechanism with rate-limiting expulsion of the leaving group. In effect. an electron-donor enhances the expulsion of the leaving group while an electron-acceptor depresses it.

The activation parameters. $\Delta H^{*}$ and $\Delta S^{\ddagger}$. determined with rate constants at three temperatures are summarized in Table 3. The $\Delta H^{*}$ values are somewhat higher but $\Delta S^{*}$ values are less negative than the corresponding values for the reactions with better leaving group $\left(\mathrm{Cl}^{-}\right)$, e.g. $\Delta H^{\ddagger}$ and $\Delta S^{\star}$ values are $10.1 \mathrm{kcal} \mathrm{mol}^{-1}$ and -47 eu for 1 ('NCS leaving group with $\mathrm{Y}=4-\mathrm{Cl}$ and $\mathrm{X}=3-\mathrm{COCH}_{3}$ ) whereas those are $4.2 \mathrm{kcal}$ $\mathrm{mol}^{-1}$ and -59 eu for $\mathrm{Y}$-aryl phenyl chlorophosphate $\left(\mathrm{Cl}^{-}\right.$ leaving group with $\mathrm{Y}=4-\mathrm{Cl}$ and $\mathrm{X}=\mathrm{H}$ ). ${ }^{3 \mathrm{a}}$ This is consistent with the stronger $\mathrm{P}-\mathrm{NCS}$ than $\mathrm{P}-\mathrm{Cl}$ bond which should be partially cleaved in the TS.

\section{Summary}

The kinetic studies of the reactions between $\mathrm{Y}$-aryl phenyl isothiocyanophosphate (1) and pyridines $\left(\mathrm{XC}_{5} \mathrm{H}_{4} \mathrm{~N}\right)$ in acetonitrile at $55.0^{\circ} \mathrm{C}$ have been carried out. The Hanmett plots for substituent $(\mathrm{Y})$ variations in the substrate $\left(\log k_{2} \times \mathrm{G}\right.$ $\sigma_{Y}$ ) show a nonlinear. convex upward curve with breaks at $Y$ 
$=\mathrm{H}$. For electron-donating groups $\left(\sigma_{\mathrm{Y}}<0\right)$ the Hammett coefficients $\rho_{\mathrm{Y}}$ are positive and $\rho_{\mathrm{XY}}$ is negative while those for electron-withdrawing groups $\left(\sigma_{Y}>0\right)$ are negative $\left(\rho_{Y}<\right.$ 0 ) with a positive $\rho_{\mathrm{X}}$. These are interpreted to indicate a concerted mechanism for the reactions with positive slopes $\left(\rho_{Y}>0\right)$ and a stepwise mechanism with rate-limiting breakdown of the TBP-5C intermediate for the reactions with negative slopes $\left(\rho_{\mathrm{Y}}<0\right)$. Biphasic plots are also obtained with $\log k_{2} v \sigma_{\mathrm{X}}$ or $\mathrm{p} K_{\mathrm{a}}(\mathrm{X})$ plots with steeper slopes for basic nucleophiles than weakly basic nucleophiles. The larger magnitudes of $\rho_{\mathrm{X}}$ and $\beta_{\mathrm{X}}$ for stronger nucleophiles are considered to arise from the front side (equatorial) nucleophilic attack. whereas the smaller values arise from the back side (apical) nucleophilic attack in the TS.

\section{Experimental Section}

Materials. GR grade pyridines were used without further purification. HPLC grade acetonitrile (water content is less than $0.005 \%$ ) was used without further purification. except drying over molecular sieve. storing under nitrogen atmosphere. and then distilled before use. Y-Aryl phenyl isothiocyanophosphates were prepared by the following two steps. In step 1. Y-aryl phenyl chlorophosphate ${ }^{24}$ was prepared by reacting phenyl dichlorophosphate with substituted phenol for six hours in the presence of triethylamine in methylene chloride on an ice bath as reported. ${ }^{3 a}$ In step 2. Yaryl phenyl isothiocyanophosphates $s^{25}$ were synthesized by reacting Y-aryl phenyl chlorophosphate with potassium thiocyanate for four hours in acetonitrile on an ice bath. The substrates were isolated in the similar way described in step 1 and were identified by TLC. IR. ${ }^{1} \mathrm{H}-\mathrm{NMR} .{ }^{13} \mathrm{C}-\mathrm{NMR}$ and GC-MS. GR Grade diphenyl chlorophosphate phenyyl dichlorophosphate. 4-chlorophenyl dichlorophosphate and potassium thiocyanate were used without further purification. The physical constants after column chromatography (silicagel/ ethylacetate $+n$-hexane) were as follows:

4-Methoxyphenyl phenyl isothiocyanophosphate. Liquid. $\delta_{\mathrm{H}}\left(\mathrm{CDCl}_{3}\right), 200 \mathrm{MHz}$. 6.72-7.4 (aromatic-H. 9H. m). 3.79 $\left(\mathrm{OCH}_{3}\right.$ str. $\left.3 \mathrm{H}, \mathrm{s}\right): \delta \mathrm{z}\left(\mathrm{CDCl}_{3}\right), 50 \mathrm{MHz}, 112-154(\mathrm{C}=\mathrm{C}$. aromatic. $12 \mathrm{C} . \mathrm{m} / \mathrm{w}), 156(\mathrm{NCS} .1 \mathrm{C} . \mathrm{w}) .53\left(\mathrm{OCH}_{\mathrm{j}}\right.$. lC. s): $v_{\text {max }}$ (neat). 3065-2985 (C-H. str. aromatic). 2835 (C-H str. aliphatic). 1977 ( $\mathrm{N}=\mathrm{C}=\mathrm{S}$. str.). 1587, 1502, $1250(\mathrm{P}-\mathrm{O}-\mathrm{Ph})$. 1311 ( $\mathrm{P}=\mathrm{O}$ str. $): m / z .321\left(\mathrm{M}^{-}\right)$.

4-Methylphenyl phenyl isothiocyanophosphate. Liquid. $\delta_{\mathrm{H}}\left(\mathrm{CDCl}_{3}\right), 200 \mathrm{MHz}, 7.14-7.50$ (aromatic-H. $9 \mathrm{H}, \mathrm{m}$ ), 2.34 $\left(\mathrm{CH}_{\hat{\jmath}}\right.$ str. $\left.3 \mathrm{H} . \mathrm{s}\right): \delta \mathrm{C}\left(\mathrm{CDCl}_{\hat{j}}\right) .50 \mathrm{MHz} .117-150(\mathrm{C}=\mathrm{C}$. aromatic. $12 \mathrm{C} . \mathrm{m} / \mathrm{w}) .132(\mathrm{NCS} . \mathrm{lC}, \mathrm{w}) .18 .2\left(\mathrm{CH}_{3} . \mathrm{lC} . \mathrm{s}\right)$ : $v_{\text {max }}$ (neat). 3042-3073 (C-H. str. aromatic). 2928 (C-H str. aliphatic) $1993(\mathrm{~N}=\mathrm{C}=\mathrm{S}$. str. $) .1587,1503.1487 .1181$ (P-O-Ph). 1311 ( $\mathrm{P}=\mathrm{O}$ str.) $m / 2.305\left(\mathrm{M}^{+}\right)$.

Diphenyl isothiocyanophosphate. Liquid. $\delta_{\mathrm{H}}\left(\mathrm{CDCl}_{3}\right)$. $200 \mathrm{MHz} .7 .15-7.40$ (aromatic-H. $10 \mathrm{H} . \mathrm{s}): \delta \mathrm{C}\left(\mathrm{CDCl}_{3}\right) .50$ $\mathrm{MHz} .117-147\left(\mathrm{C}=\mathrm{C}\right.$. aromatic), 128 (NCS): $v_{\max }$ (neat). 3065-3073 (C-H. str. aromatic). $1985(\mathrm{~N}=\mathrm{C}=\mathrm{S}$. str.). 1587. 1487. 1200 ( $\mathrm{P}-\mathrm{O}-\mathrm{Ph}$ ). 1311 ( $\mathrm{P}=\mathrm{O}$ str) $): m / z .291\left(\mathrm{M}^{-}\right)$.

3-Methoxyphenyl phenyl isothiocyanophosphate. Liquid.
$\delta_{\mathrm{H}}\left(\mathrm{CDCl}_{3}\right.$ ). $200 \mathrm{MHz} .6 .72-7.5$ (aromatic-H. $9 \mathrm{H} . \mathrm{m} / \mathrm{s}$ ). 3.79 $\left(\mathrm{OCH}_{2}\right.$ str. $\left.3 \mathrm{H}, \mathrm{s}\right): \delta,\left(\mathrm{CDCl}_{3}\right), 50 \mathrm{MHz} .103-158(\mathrm{C}=\mathrm{C}$. aromatic. $12 \mathrm{C} . \mathrm{m} / \mathrm{w}) .124$ (NCS. 1C. w). $53\left(\mathrm{OCH}_{3}\right.$. lC. s): $V_{\max }$ (neat). 3071-2946 (C-H. str. aromatic), 2838 (C-H str. aliphatic), $1980(\mathrm{~N}=\mathrm{C}=\mathrm{S}, \mathrm{str}), 1621.1502,1458,1290$ (P-O-Ph), 1317 ( $\mathrm{P}=\mathrm{O}$ str.): $m / z .321\left(\mathrm{M}^{-}\right.$).

4-Chlorophenyl phenyl isothiocyanophosphate. Liquid. $\delta_{\mathrm{H}}\left(\mathrm{CDCl}_{3}\right), 200 \mathrm{MHz}$. 7.18-7.4 (aromatic-H. $\left.9 \mathrm{H}, \mathrm{m} / \mathrm{s}\right): \delta \mathrm{c}$ $\left(\mathrm{CDCl}_{3}\right), 50 \mathrm{MHz}, 117-148(\mathrm{C}=\mathrm{C}$, aromatic, $12 \mathrm{C}, \mathrm{m} / \mathrm{w})$. 129 (NCS. IC . w): $v_{\max }$ (neat), 3103-3062 (C-H. str. aromatic). $1955(\mathrm{~N}=\mathrm{C}=\mathrm{S}$. str. $) .1600 .1497,1450(\mathrm{P}-\mathrm{O}-\mathrm{Pl}), 1311(\mathrm{P}=\mathrm{O}$ str.): $m / z, 325\left(\mathrm{M}^{+}\right)$.

Kinetics measurement. Rates were measured conductometrically at $55.0{ }^{\circ} \mathrm{C}$ for the reactions of aryl phenyl isothiocyanophosphate with pyridines using a computer controlled conductivity bridge constructed in this laboratory. Pseudo-first-order rate constants. $k_{\text {ctsd. }}$ were measured by using curve fitting method in ORIGIN program (version 5.1) or Guggenheim method. ${ }^{? i}$ Pseudo-first-order rate constants were determined with large excess of nucleophiles. [substrate] $=1 \times 10^{3} \mathrm{M}$ and [nucleophile] $=0.1-0.5 \mathrm{M}$. Pseudofirst-order rate constant values were average of three nuns which were reproducible within $\pm 3 \%$.

Product analysis. 4-Methoxyphenyl phenyl isothiocyanophosphate was refluxed with excess pyridine for more than 15 half-lives at $55^{\circ} \mathrm{C}$ in acetonitrile. Acetonitrile was evaporated under reduced pressure. 4-Methoxyphenyl phenyl phosphoropyridinium thiocyanate was isolated by removing excess pyridine using column-chromatography teclunique. It is important to notice that the product was collected from the upper most part silica-gel of the colunn by washing with acetonitrile solvent. Then solvent was evaporated under reduced pressure. The plysical constants after column chromatography (silica-gel/ethyl acetate $+n$-hexane) were as follows:

$\left[\left(+-\mathrm{OCH}_{3} \mathrm{C}_{6} \mathrm{H}_{4} \mathrm{O}\right)\left(\mathrm{C}_{6} \mathrm{H}_{5} \mathrm{O}\right) \mathbf{P}(=\mathbf{0})\left(\mathrm{NC}_{5} \mathrm{H}_{5}\right)\right]^{+}(\mathrm{NCS})^{-}$. Liquid. $\delta_{\mathrm{H}}$ (DMSO), $200 \mathrm{MHz}$, 6.76-8.6 (including pyridine aromatic-H. $14 \mathrm{H} . \mathrm{m} / \mathrm{w}) .3 .6\left(\mathrm{OCH}_{2}, 3 \mathrm{H} . \mathrm{s}\right): \delta$ (DMSO). 50 $\mathrm{MHz}, 118-153$ (including pyridine aromatic $-\mathrm{C}, 17 \mathrm{C}, \mathrm{w}$ ). 112 (NCS. 1C. w) $53.5\left(\mathrm{OCH}_{3} .1 \mathrm{C} . \mathrm{s}\right): v_{\max }$ (neat), 29583103 (C-H str. aromatic). 2843 (C-H str.. aliphatic), 2070 (SCN). 1717 (C-N str.. aromatic). 1602. 1510. 1379 (P-O-Ph). $1250(\mathrm{P}=\mathrm{O})$.

4-Chlorophenyl phenyl isothiocyanophosphate was refluxed with excess pyridine as described above.

$\left[\left(+-\mathrm{ClC}_{6} \mathrm{H}_{4} \mathrm{O}\right)\left(\mathrm{C}_{6} \mathrm{H}_{5} \mathrm{O}\right) \mathrm{P}(=\mathrm{O})\left(\mathrm{NC}_{5} \mathrm{H}_{5}\right)\right]^{+}\left(\mathrm{NCS}^{-}\right.$. Liquid. $\delta_{\mathrm{H}}\left(\mathrm{CDCl}_{2}\right), 200 \mathrm{MHz}, 7.076-7.345$ (including pyridine aromatic-H. $14 \mathrm{H} . \mathrm{m} / \mathrm{w}): \delta\left(\mathrm{CDCl}_{2}\right)$. $50 \mathrm{MHz}$. $120.485-$ 150.5 (including pyridine aromatic-C. $17 \mathrm{C}, \mathrm{w}$ ): $v_{\text {max }}$ (neat). 3071-3098 (C-H str., aromatic). 2865 (C-H str.. aliphatic). 1583. 1496.1306 ( $\mathrm{P}-\mathrm{O}-\mathrm{Ph}) .1187(\mathrm{P}=\mathrm{O})$.

4-Cllorophenyl phenyl isothiocyanophosphate was refluxed with excess 4-methy lpyridine as described above.

$\left[\left(4-\mathrm{ClC}_{6} \mathrm{H}_{4} \mathrm{O}\right)\left(\mathrm{C}_{6} \mathrm{H}_{5} \mathrm{O}\right) \mathrm{P}(=\mathbf{0})\left(4-\mathrm{CH}_{3} \mathrm{NC}_{5} \mathrm{H}_{5}\right)\right]^{+}(\mathrm{NCS})^{-}$. Liquid. $\delta_{\mathrm{H}}\left(\mathrm{CDCl}_{3}\right), 200 \mathrm{MHz} .7 .08-8.40$ (including pyridine aromatic-H. $14 \mathrm{H}, \mathrm{m} / \mathrm{w}) .2 .61\left(\mathrm{CH}_{3} .3 \mathrm{H}, \mathrm{s}\right): \delta \mathrm{C}\left(\mathrm{CDCl}_{3}\right), 50$ $\mathrm{MHz} .120 .26-152.25$ (including pyrridine aromatic-C. $17 \mathrm{C}$. 
w). 159.25 (NCS, 1C, w). $22.38\left(\mathrm{CH}_{3}, 1 \mathrm{C}, \mathrm{s}\right): v_{\text {max }}$ (neat). 3066-3093 (C-H str., aromatic). 2865 (C-H str. aliphatic). 2065 (NCS str) $, 1589.1485,1310$ (P-O-Ph), $1165(\mathrm{P}=\mathrm{O}) . \delta_{\mathrm{p}}$ $\left(\mathrm{CDCl}_{3}\right), 162 \mathrm{MHz} .+5.77(\mathrm{P}=\mathrm{O} .1 \mathrm{P} . \mathrm{s})$.

Acknowledgement. This work was supported by Korea Research Foundation Grant (KRF-2002-070-C00061).

\section{References}

1. (a) Page, M.: Walliams. A. Organic and Bio-Organic Hechonisnts: Longman: Harlow: 1997: Chapter 7-8. (b) Williams. A. Concented Orgamic and Bio-Organic Hechamisms: CRC Press: Boca Raton. 2000: Chapter 6. (c) Hudson. R. F. Structure and Hechamism in Organophosphorus Chemistry: Academic Press: New York. 1965. (d) Adninial. S. J: Schneider, B.: Mever, P; Janin. J: Veron, M.: Deville-Bonne, D; Herschlag. D. Biochemistr 1999. $38,4701$. (e) Mol C. D.: Izlumi. T.: Mitra. S.: Tainer. I. A Nahre $\mathbf{2 0 0 0}+103$. 451. (f) Hostield. D. J.: Guan. Y: Haas. B. J.: Cunningham. R. P.: Tainer. J. A. Cell 1999. 98. 397. (g) Mol. C. D.: Hosfield. D. J.: Tainer. J. A. Mtutat. Res. 2000. t60. 211. (h) Chapados. B. R.: Chai, Q: Hostield. D. J: Qiu, J: Shen, B: Tainer, J. A. J. Wol. Biol. 2001. 307. 541 .

2. (a) Boume, N.: Williams, A. J. Am. Chem. Soc, 1984, 106. 7591. (b) Skoog. M. T.: Jencks. W. P. J. Am. Chem. Soc. 1984. 106. 7597. (c) Bourne. N.: Chrystiuk. E.: Davids. A. M.: Williams. A. J.Am. Chem. Soc. 1988. 110.890. (d) Ba-Sait. S. A.: Waring. M. A.: Williams A. J An Chent Soc. $1990,112.8115$. (e) Cho $\mathrm{H}$ : Krishnaraj. R.: Kiats. E.: Bannwarth. W.: Walsh. C. T.: Anderson, K. S. J. Am. Chem. Soc. 1992, 114. 7296. (f) Kirby, A. J.: Varrogils. A. G. J. Am. Chem. Soc. 1967. 89.415. (g) Friedman. J. M: Freeman. S.: Knowles. J. R. J. Am. Chem. Soc 1988. 110. 1268. (h) Hofti. R. H.: Hengge. A. C. J. Org. Chem. 1998. 63. 6680. (i) Popov. A. F.: Sadovshii, Y. S.: Solomoichenko. T. N.: Savelova. V. A. Lobanova. O. V.: Piskunova, Z. P. Russ. J. Org. Chem. 2000.36 .715 .

3. (a) Guha. A. K.: Lee. H. W.: Lee. I. J. Chem. Soc. Perhin Trans. 2 1999. 765. (b) Guha. A. K.: Lee. H. W.: Lee. I. J. Org. (Them. 2000. 65. 15. (c) Lee. H. W. Guha. A. K.: Lee. I. Iht. J. Chent. Finet. 2002. 34.632

4. Lee, H. W.: Guha, A. K: Kim, C. K: Lee. I. J. Org Chem. 2002. 67,2215

5. Mo. B.: Li. J.: Liang. S. Anal Biochem. 1997, 252. 169.

6. Bailey. J. M. : Nikfarjam. F.: Shenoy. J. E. Protem Sci. 1992. 1. 1622 .

7. Bernat I: Kristian, P: Guspanova, I.: Innich. J.: Busova, T. Collec Czech Chem Conm 1997.62. 1491.

8. (a) Lee, I. Chem. Soc. Rev 1990, 19, 317. (b) Lee. I. Adx. Phss. Org. Chem. 1992. 27. 57. (c) Lee. I.: Lee. H. W. Collec. Czech. Chem. Comm. 1999. 64. 1529. (d) Isaacs. N. S. Physical Organic Chemistiv. 2nd ed.: Longmant: Harlow 1995: p 186.

9. (a) Lee, I.: Kim. C. K: Han. I. S : Lee. H. W: Kim, W. K.: Kim. Y. B. J. Phis. Chem. B 1999. 103, 7302. (b) Coetzee I. F. Prog. Phys. Org. Chem. 1965. 4. 45. (c) Spillane. W. J.: Hogan. G.: McGrath. P.: King. J.: Brack. C. J. Chem. Soc. Perhin Trans. 2 1996. 2099. (d) Ritchie. C. D. Solute Solvem Interactions: Marcel-
Dekker: New York, 1969: p 228. (e) Koh. H. J.: Han, K. L.; Lee, H. W. Lee, I. J. Org. Chem. 1998, 63,9834.

10. (a) John1son1. C. D. The Hammett Equation: University Press: Cambridge. 1973: Chapter 2. (b) Rutf. F.: Csizmadia. I. G. Organic Reactions Equilibria, Kinetics and Hechanisnt. Elsevier: Amsterdam. 1994; Chapter 7.

11. (a) Oh, H. K: Yang. J. H.: Sung, D. D.; Lee, I. J. Chem. Soc., Prohin Trans. 2 2000. lol (b) Oh, H. K.: Yang. J. H.: Lee, H. W: Lee. I. J. Org. Chem. 2000. 65. 2188 . (c) Oh. H. K: Yang. J. H.: Lee. H. W. Lee. I. J. Org. Chem. 2000. 65.5391. (d) Oh. H. K: Kinn. T. S.: Lee. H. W.: Lee. I. J. Chent. Soc. Perkin Trans. 2 2002. 282

12. Koh, H. J.: Han. K. L.: Lee. H. W.: Lee. I. J. Ong Chen $2000,65$. 4706.

13. (a) Bond. P. M.: Moodie. R. B. J. Chem. Soc., Pemhin Trans. 2 1976. 679. (b) Castro. E. A.: Gil. F. J. J. Am. Chem. Soc. 1977. 99. 7611. (c) Satterthwait. A.: Jenchs. W. P. J. Ant. Chent. Soc. 1974. 96. 7018. 7031. (d) Castro. E. A.: Leandro, L: Millan. P; Santos. J. G. J. Org Chem. 1999. 6t. 1953.

14. Rowell, R.: Gorenstein, D. G. J. Am. Chem. Soc. 1981. 103. 5894.

15. (a) Gresser. M. J.: Tencks. W. P. J. Am. Chem. Soc. 1977. 99.6963. 6970. (b) Castro. E. A.: Ibanez. F.: Salas. M.: Santos. T. G. J. Org. Chent 1991. 56. 4819. (c) Castro. E. A.: Culbillos. M.: Ibanez. F.: Maraga I.: Santos. J. G. J. Org Chem. 1993. 58. 5400 (d) Castro. E. A.: Cubillos. M.: Santos, J. G. J. Otg. Chem. 1996. 61. 3501 (e) Song, B. D.: Jencks. W. P. J. Am. Chem. Soc. $1989,111,8479$. (f) Lee. D.: Kinn. C. K.: Lee. B.-S.: Lee. I. Bull. Kowan Chem. Soc. 1995. 16. 1203. (g) Lee. I.: Kiml. C. K.: Li. H. G.: Sohn1. C. K.: Kim. C. K.: Lee. H. W. Lee B.-S. J. Am. Chem. Soc 2000. 122. 11162 .

16. (a) Perozzi, E. F.: Martin, J. C.: Paul , I. C. J. An Chem. Soc. 1975. 96. 6735. (b) Ramirez. F. Acc. Chem. Res. 1968. 1. 168. (c) McDowell. R. S.: Streitwieser. A. J.Am. Chem. Soc. 1985. 107. 5849. (d) Lee. I.: Kim. C. K.: Lee. B.-S.: Ha. T.-K. THEOCHEM 1993. 279. 191 .

17. Kim. T.-H.; Huh. C.: Lee. B.-S: Lee. I. J. Chent Soc. Perkin Trans. $21995,2257$.

18. Lee. I.: Koh, H. J. Kew d. Chem. 1996. 20, 131.

19. (a) Oh. H. K.: Shin. C. H.: Lee. I. J. Chem. Soc. Perkin Trans. 2 1995. 1169. (b) Oh. H. K.: Shin. C. H.: Lee. I. Bull Korean Chem. Soc. 1995. 16.657 .

20. (a) Castro, E. A.; Ibanez. F; Salas. M.: Santos. J. G.; Sepulveda, P. J. Org. Chen 1993, 58. 459. (b) Castro. E. A.: Cubillos, M: Santos. J. G. J. Org. Chem 2001. 66,6000.

21. (a) Epiotis. N. D.: Cherry. W. R.: Shaik. S.: Yates. R. L.: Bernardi. F. Structwal Theory of Organic Chomistry: Springer-Verlag: Berlin. 1977: Part 1. (b) Glendening. E. D.: Weinhold. F. J. Contput. Chent 1998, 19,610. (c) Fleming. I. Frontier Orbitals and Organic Chemical Reactions. Wiley: London, 1976: Chapter 4.

22. (a) Reed, R. E.: Curtiss, L. A.; Weinhold. F. Chem. Rev 1988.88. 899. (b) Tyrrell. J.: Weinstock. R. B.: Weinhold. F. Int. J. Quant. Chem. 1981.19.781.

23. Lee. I.: Lee. D.: Kim. C. K. J. Ph.s. Chent A 1997. 101.879.

24. Wadsworth. W. S.: Wilde, R. L. J. Org Chem. 1976, 11, 1264

25. (a) Bernat. J.: Kristian, P: Guspanova, J.: Imrich. J.: Busova, T. Collect. Czech. Chem. Conmm 1997, 62, 1491. (b) Tomaschewski, G.: Zanke. D. Z. Chem 1971. 11.384.

26. Guggenheim. E. A. Philos. Mag. 1926. 2.538. 